\title{
Poor sensitivity of "AccuPower SARS-CoV-2 real time RT-PCR kit (Bioneer, South Korea)"
}

\author{
Byron Freire-Paspuel and Miguel Angel Garcia-Bereguiain*
}

\begin{abstract}
Background: Several molecular kits are available for SARS-CoV-2 diagnosis, mostly lacking of proper clinical evaluation due to the emergency caused by COVID19 pandemia, particularly at developing countries like Ecuador.

Objective: We carried out an evaluation of the clinical performance of "AccuPower SARS-CoV-2 Real Time RT-PCR kit" (Bioneer, South Korea) for SARS-CoV-2 diagnosis using 2019-nCoV CDC EUA kit (IDT, USA) as a gold standard.

Results: 48 clinical specimens were included on the study, 38 tested SARS-CoV-2 positive and 10 SARS-CoV-2 negative for 2019-nCoV CDC EUA kit. For "AccuPower SARS-CoV-2 Real Time RT-PCR kit", only 30 were SARS-CoV-2 positive, indicating a low clinical performance with sensitivity of 78.9\%. Moreover, the limit of detection for "AccuPower SARSCoV-2 Real Time RT-PCR kit" was estimated to be higher than 40,000 viral RNA copies/mL of sample.

Conclusions: Proper clinical performance evaluation studies from government agencies at developing countries should be mandatory prior to clinical use authorization of SARS-CoV-2 diagnosis kits, particularly when those kits lack of either FDA or its country of origin clinical use authorization, to prevent the distribution of low quality products that may have a negative impact of COVID19 surveillance at developing countries.
\end{abstract}

Keywords: SARS-CoV-2, RT-PCR, CDC, Bioneer

\section{Introduction}

The COVID19 outbreaks has challenged public health systems worldwide, particularly at developing countries. Not only patient cares or surveillance programs are overflow, but also the capacity for regulatory agencies to guarantee the quality of SARS-CoV-2 related diagnosis tools. For instance, multiple SARS-CoV-2 molecular diagnosis kits are available on the market, mostly based on RT-qPCR. Some of them have received emergency use authorization (EUA) from the U.S. Food and Drug Administration (FDA) [1], or at least by regulatory agencies at their country of production, while others only report clinical evaluation studies made by manufacturers.

The CDC designed 2019-nCoV CDC EUA kit (IDT, USA) is based on N1 and N2 gene targets to detect SARS-CoV-2 that have received positive evaluation on

*Correspondence: magbereguiain@gmail.com

One Health Research Group, Universidad de Las Américas, Quito, Ecuador recent reports, and RNaseP target as a quality control of the RNA extraction; it is considered a gold standard for clinical evaluation worldwide [2-6].

"AccuPower SARS-CoV-2 Real Time RT-PCR kit " (Bioneer, South Korea) is a RT-qPCT kit that include two gene targets "RdRp" and "E" for SARS-CoV-2 detection, a "IPC" probe for PCR inhibition control, but no gene target for RNA extraction quality control. Although this kit lacks of EUA approval from FDA (USA) and from Korean CDC [1, 7], it has CE mark and is currently available in countries like Ecuador, Mexico and Colombia for in vitro SARS-CoV-2 clinical diagnosis.

The aim of this study was to evaluate the clinical performance in terms of sensitivity and limit of detection for "AccuPower SARS-CoV-2 Real Time RT-PCR kit " using 2019-nCoV CDC EUA kit as a gold standard for SARSCoV-2 RT-qPCR diagnosis from nasopharyngeal samples. original author(s) and the source, provide a link to the Creative Commons licence, and indicate if changes were made. The images or other third party material in this article are included in the article's Creative Commons licence, unless indicated otherwise in a credit line to the material. If material is not included in the article's Creative Commons licence and your intended use is not permitted by statutory regulation or exceeds the permitted use, you will need to obtain permission directly from the copyright holder. To view a copy of this licence, visit http://creativecommons.org/licenses/by/4.0/. The Creative Commons Public Domain Dedication waiver (http://creativeco mmons.org/publicdomain/zero/1.0/) applies to the data made available in this article, unless otherwise stated in a credit line to the data. 


\section{Material and methods}

\section{Study design}

48 clinical specimens (nasopharyngeal swabs collected on $0.5 \mathrm{~mL}$ TE pH 8 buffer) were included on this study, coming from individuals attending Universidad de Las Américas laboratory for SARS-CoV2 diagnosis in Quito (Ecuador). Also, 4 negative controls (TE pH 8 buffer) were included as control for carryover contamination, one for each set of RNA extractions.

\section{RNA extraction and RT-qPCR for SARS-CoV-2 diagnosis using 2019-nCoV CDC kit}

All the samples included on the study were tested following a modified version of the CDC protocol: (1) using "AccuPre Viral RNA extraction kit IVD" (Bioneer, South Corea) as an alternate RNA extraction method; (2) using CFX96 BioRad instrument [2, 3, 6, 8, 9]. Final volume of RT-PCR reaction was $15 \mathrm{ul}$ including $4 \mathrm{uL}$ of RNA extraction.

\section{SARS-CoV-2 diagnosis using "AccuPower SARS-CoV-2 Real Time RT-PCR kit"}

Same RNA extractions from all the samples included on the study were tested using "AccuPower SARSCoV-2 Real Time RT-PCR kit" following manufacturer's intructions (see Additional file 1). Final volume of RT-PCR reaction was $25 \mu \mathrm{l}$ including $5 \mu \mathrm{L}$ of RNA extraction (for a detailed comparison among both kits see Table 3). Although RNA extraction were tested with both RT-PCR protocols within $48 \mathrm{~h}$, the quality of RNA was assured by running RT-qPCR for RNaseP probe.

\section{Analytical sensitivity}

Limit of detection (LoD) was performed using the 2019-nCoV N positive control (IDT, USA) provided at 200,000 genome equivalents/mL for 2019-nCoV CDC FDA EUA kit. As $40 \mu \mathrm{L}$ of elution buffer volumen and $200 \mu \mathrm{L}$ of sample are used in the RNA extraction protocol, a 200 conversion factor applied to change LoD units from copies/ $\mu \mathrm{L}$ of RNA solution to copies $/ \mathrm{mL}$ of sample. For instance, 10 copies/ $\mu \mathrm{L}$ of RNA extraction are equivalent to 2000 copies/mL of sample. For "AccuPower SARS-CoV-2 Real Time RT-PCR kit ", a positive control is included on the kit but the concentration is not detailed, so it was not possible to directly determine LoD.

\section{Results}

Clinical performance of "AccuPower SARS-CoV-2 real time RT-PCR kit " compared to the CDC gold standard protocol 48 samples were tested for SARS-CoV-2 following both protocols described on the methods. 10 samples tested negative for either 2019-nCoV CDC EUA kit or "AccuPower SARS-CoV-2 Real Time RT-PCR kit", indicating a specificity of $100 \% .38$ samples tested positive for 2019-nCoV CDC EUA; from those samples, 30 samples tested positive for either $E$ and RdRp gene targets (23 true positives samples) or RdRp gene target only (7 inconclusive samples) for the "AccuPower SARS-CoV-2 Real Time RT-PCR kit", indicating a sensitivity of $78.9 \%$ (95\% CI: 65.98-91.9\%) (Tables 1 and 2). If we considered as positive samples, only true positive samples with RdRp and E gene targets amplification, the sensitivity for "AccuPower SARS-CoV-2 Real Time RT-PCR kit" would be $60.5 \%$ (95\% CI: 50.7-70.6\%). The quality of RNA extractions was assured by running RT-qPCR for RNaseP gene target for each RT-PCR protocol; no statistically significant differences were found for $\mathrm{RNa}$ saP Ct values.

\section{Estimation of the limit of detection of "AccuPower} SARS-CoV-2 Real Time RT-PCR kit"

The viral loads detailed on Table 2 were calculated running a calibration curve with $2019-\mathrm{nCoV} \mathrm{N}$ positive control (IDT, USA). The LoD for the CDC protocol was set at 1000 viral RNA copy per mL of sample (or 5 RNA copies/ $\mu \mathrm{L}$ of RNA extraction solution) on previous studies [2, 6, 8-11]. Although LoD could not be calculated for "AccuPower SARS-CoV-2 Real Time RT-PCR kit" as we described on the methods, no true positive samples were obtained below 40.000 RNA copies/mL of sample (200 RNA copies/ $\mu \mathrm{L}$ of RNA extraction solution) according to the CDC protocol; even the sample 13617 (Table 2) with a viral load of 453 copies/ $\mu \mathrm{L}(90,600$ copies/mL of sample) was not detected by "AccuPower SARS-CoV-2 Real Time RT-PCR kit". As the LoD is defined as the lowest viral load in which all samples are detected (100\% sensitivity), our data indicates that the LoD for "AccuPower SARS-CoV-2 Real Time RT-PCR kit" is higher than 40,000 RNA copies/mL of sample, and even higher that 90,600 RNA copies/mL of sample if we considered the result for sample 13617 .

Table 1 Clinical performance of " AccuPower SARS-CoV-2 Real Time RT-PCR kit " compared to "2019-nCoV CDC EUA kit". Value of $100 \%$ and $78.9 \%$ (95\% Cl: 65.98-91.9\%) corresponds to specificity and sensitivity, respectively

\begin{tabular}{lll}
\hline & $\begin{array}{l}\text { "AccuPower SARS- } \\
\text { CoV-2" Positive }\end{array}$ & $\begin{array}{l}\text { "AccuPower } \\
\text { SARS-CoV-2" } \\
\text { Negative }\end{array}$ \\
\hline "2019-nCoV CDC" POSITIVE & $30(78.9 \%)$ & 8 \\
"2019-nCoV CDC" NEGATIVE & 0 & $10(100 \%)$ \\
\hline
\end{tabular}


Table 2 Ct values and viral loads (viral RNA copies/uL of RNA extraction solution) for samples processed with "2019-nCoV CDC EUA kit" and "'AccuPower SARS-CoV-2 kit"

\begin{tabular}{|c|c|c|c|c|c|c|c|c|c|c|c|}
\hline \multirow[t]{2}{*}{ Sample } & \multirow[t]{2}{*}{ Sample ID } & \multicolumn{5}{|l|}{ 2019-nCoV CDC EUA } & \multicolumn{5}{|c|}{ Accupower SARS-CoV-2 (Bioneer) } \\
\hline & & Viral Load (copies/uL) & $\mathrm{N} 1 \mathrm{Ct}$ & $\mathrm{N} 2 \mathrm{Ct}$ & $\mathrm{RPCt}$ & Result CDC & $\mathrm{ECt}$ & IPC (M1)Ct & $\mathrm{RdRp} C \mathrm{t}$ & IPC (M2) Ct & Result Bioneer \\
\hline 1 & 13517 & $2.03 \times 10^{7}$ & 12.16 & 13.13 & 20.16 & Positive & 15.38 & 25.95 & 15.38 & 25.67 & Positive \\
\hline 2 & 11957 & $1.11 \times 10^{7}$ & 13.08 & 14.04 & 27.02 & Positive & 16.10 & 26.31 & 16.19 & 26.14 & Positive \\
\hline 3 & 13645 & $2.32 \times 10^{6}$ & 16.15 & 17.21 & 21.28 & Positive & 23.25 & 25.44 & 21.69 & 26.10 & Positive \\
\hline 4 & 11971 & $6.10 \times 10^{5}$ & 17.50 & 18.78 & 23.35 & Positive & 21.31 & 26.06 & 21.29 & 25.92 & Positive \\
\hline 5 & 13466 & $2.04 \times 10^{5}$ & 19.17 & 21.31 & 21.01 & Positive & 23.06 & 25.52 & 22.27 & 25.81 & Positive \\
\hline 6 & 13468 & $1.61 \times 10^{5}$ & 19.53 & 22.02 & 20.23 & Positive & 23.47 & 25.94 & 23.50 & 25.99 & Positive \\
\hline 7 & 12116 & $1.36 \times 10^{5}$ & 20.57 & 20.66 & 24.29 & Positive & 27.01 & 26.78 & 25.26 & 26.07 & Positive \\
\hline 8 & 12397 & $1.20 \times 10^{5}$ & 21.61 & 22.25 & 21.04 & Positive & 24.28 & 25.93 & 24.11 & 24.93 & Positive \\
\hline 9 & 13441 & $2.75 \times 10^{4}$ & 22.70 & 23.62 & 24.34 & Positive & 26.26 & 26.00 & 26.06 & 25.65 & Positive \\
\hline 10 & 11944 & $1.79 \times 10^{4}$ & 24.02 & 24.69 & 20.54 & Positive & 27.20 & 26.09 & 27.55 & 26.03 & Positive \\
\hline 11 & 13632 & $1.66 \times 10^{4}$ & 23.26 & 24.60 & 23.83 & Positive & 28.12 & 25.62 & 27.93 & 25.89 & Positive \\
\hline 12 & 12121 & $2.12 \times 10^{3}$ & 26.87 & 27.39 & 19.30 & Positive & 30.23 & 26.03 & 31.12 & 25.65 & Positive \\
\hline 13 & 13469 & $1.58 \times 10^{3}$ & 26.58 & 29.64 & 23.00 & Positive & 30.34 & 25.82 & 31.27 & 25.75 & Positive \\
\hline 14 & 12079 & $1.46 \times 10^{3}$ & 27.23 & 28.06 & 20.15 & Positive & 29.60 & 25.99 & 30.23 & 25.74 & Positive \\
\hline 15 & 12123 & $7.49 \times 10^{2}$ & 28.41 & 29.09 & 20.07 & Positive & 31.60 & 25.90 & 32.98 & 25.68 & Positive \\
\hline 16 & 12092 & $6.24 \times 10^{2}$ & 28.68 & 29.24 & 19.36 & Positive & 32.06 & 26.04 & 33.23 & 25.98 & Positive \\
\hline 17 & 13617 & $4.53 \times 10^{2}$ & 28.66 & 31.31 & 21.41 & Positive & NA & 28.98 & NA & 26.33 & Negative \\
\hline 18 & 11949 & $4.34 \times 10^{2}$ & 28.71 & 30.48 & 22.40 & Positive & 33.08 & 26.42 & 33.85 & 26.19 & Positive \\
\hline 19 & 13653 & $4.24 \times 10^{2}$ & 28.54 & 30.37 & 19.11 & Positive & 31.67 & 25.87 & 33.00 & 25.79 & Positive \\
\hline 20 & 13523 & $3.56 \times 10^{2}$ & 28.96 & 31.21 & 17.39 & Positive & 31.73 & 26.17 & 32.27 & 26.03 & Positive \\
\hline 21 & 13598 & $3.37 \times 10^{2}$ & 29.03 & 31.07 & 19.15 & Positive & 32.77 & 25.63 & 34.33 & 25.54 & Positive \\
\hline 22 & 13560 & $2.97 \times 10^{2}$ & 29.19 & 30.64 & 19.42 & Positive & NA & 25.93 & 35.54 & 25.81 & Inconclusive \\
\hline 23 & 12107 & $2.66 \times 10^{2}$ & 29.94 & 30.92 & 19.65 & Positive & 34.02 & 26.23 & 20.16 & 24.55 & Positive \\
\hline 24 & 11967 & $2.50 \times 10^{2}$ & 29.39 & 32.14 & 23.86 & Positive & 32.74 & 25.81 & 34.08 & 25.79 & Positive \\
\hline 25 & 9224 & $2.23 \times 10^{2}$ & 29.47 & 30.94 & 24.89 & Positive & 33.16 & 26.06 & 33.20 & 26.13 & Positive \\
\hline 26 & 9220 & $1.97 \times 10^{2}$ & 29.65 & 31.07 & 27.88 & Positive & NA & 26.09 & 37.73 & 26.22 & Inconclusive \\
\hline 27 & 12451 & $1.36 \times 10^{2}$ & 30.18 & 32.29 & 23.53 & Positive & NA & 26.08 & 35.07 & 25.66 & Inconclusive \\
\hline 28 & 13489 & $1.06 \times 10^{2}$ & 30.49 & 32.88 & 20.17 & Positive & NA & 25.64 & 34.88 & 25.74 & Inconclusive \\
\hline 29 & 13522 & $9.17 \times 10^{1}$ & 30.68 & 34.30 & 18.99 & Positive & NA & 26.07 & 36.57 & 25.72 & Inconclusive \\
\hline 30 & 13644 & $8.10 \times 10^{1}$ & 30.92 & 32.81 & 22.91 & Positive & NA & 25.81 & NA & 25.70 & Negative \\
\hline 31 & 13636 & $6.20 \times 10^{1}$ & 31.31 & 34.54 & 23.44 & Positive & NA & 26.04 & NA & 25.67 & Negative \\
\hline 32 & 11966 & $5.73 \times 10^{1}$ & 31.63 & 33.47 & 25.19 & Positive & NA & 25.87 & 36.38 & 25.69 & Inconclusive \\
\hline 33 & 11948 & $3.33 \times 10^{1}$ & 31.96 & 35.35 & 22.13 & Positive & NA & 26.31 & 36.61 & 26.03 & Inconclusive \\
\hline 34 & 13674 & $1.92 \times 10^{1}$ & 32.65 & 36.06 & 21.26 & Positive & NA & 25.76 & NA & 25.61 & Negative \\
\hline 35 & 13521 & $1.10 \times 10^{1}$ & 34.15 & 36.61 & 21.26 & Positive & NA & 26.29 & NA & 26.03 & Negative \\
\hline 36 & 11946 & 6.77 & 33.97 & 38.15 & 21.97 & Positive & NA & 26.02 & NA & 25.78 & Negative \\
\hline 37 & 13616 & 4.45 & 34.50 & 38.68 & 19.66 & Positive & NA & 25.99 & NA & 25.77 & Negative \\
\hline 38 & 13630 & 2.87 & 34.88 & 38.58 & 23.17 & Positive & NA & 25.60 & NA & 25.49 & Negative \\
\hline
\end{tabular}

A comparison among AccuPower SARS-CoV-2 Real Time RT-PCR and 2019-nCoV CDC EUA kits, including price per reaction for the Ecuadorian market, is detailed in Table 3.

\section{Discussion}

The data presented on this work supports that "AccuPower SARS-CoV-2 Real Time RT-PCR kit" has a low clinical performance with at least a reduction of $21.1 \%$ 
Table 3 Comparison of 2019-nCoV CDC EUA (IDT, USA) and Accupower SARS-CoV-2 (Bioneer, South Korea) kits. Price per PCR reaction is for reagents only at Ecuadorian market values (RP target for IDT kit is for RNA extraction quality control, absent on Bioneer kit)

\begin{tabular}{lll}
\hline SARS-CoV-2 RT-PCR kit & Gene targets & Limit of detection \\
& $\begin{array}{l}\text { Price } \\
\text { per PCR } \\
\text { reaction }\end{array}$ & 1000 viral copies $/ \mathrm{mL}$ \\
2019-nCoV CDC EUA (IDT, USA) & N1, N2 and RP & $>40,000$ viral copies $/ \mathrm{mL}$ \\
\hline
\end{tabular}

on sensitivity compared to 2019-nCoV CDC FDA EUA, even up to $39.5 \%$ reduction if we do not consider the inconclusive samples with only $\mathrm{RdRp}$ amplification as positive. Also, the lack of any probe for RNA extraction quality control like RNaseP and the unreported concentration of positive controls provided for "AccuPower SARS-CoV-2 Real Time RT-PCR kit" that does not allow viral load calculations, are limitations to consider prior to use this kit. As we have described above, the LoD for "AccuPower SARS-CoV-2 Real Time RTPCR kit" is estimated to be even higher than 90,600 viral copies $/ \mathrm{mL}$, as sample 13617 was not detected. Although the main limitation of our study is the sample size, we believe that our results are sufficient to conclude that the LoD for "AccuPower SARS-CoV-2 Real Time RT-PCR kit" is at least above 40,000 RNA copies/ $\mathrm{mL}$ of sample. Considering the viral loads frequency distribution for SARS-CoV-2 reported to date, this high LoD would potentially exclude at least more than $20 \%$ of true positive cases if "AccuPower SARS-CoV-2 Real Time RT-PCR kit" is used for surveillance programs $[12,13]$.

"AccuPower SARS-CoV-2 Real Time RT-PCR kit" neither has EUA FDA approval nor Korean CDC EUA approval $[1,7]$, so it is not actually used for clinical diagnosis on its country of origin. However, it is available in Ecuador, where no evaluation studies were carried out by the governmental regulatory agency responsible for clinical use authorization for SARS$\mathrm{CoV}-2$ diagnosis.

\section{Conclusions}

Worldwide high demand of reagents for SARS-CoV RTqPCR diagnosis and supplies shortage is a fact, affecting even harder to developing countries like Ecuador. The poor sensitivity of "AccuPower SARS-CoV-2 Real Time RT-PCR kit" suggests that clinical performance studies should be mandatory to guarantee the quality of the supplies in the market for every country in the world. Our study aims to be a call for action to prevent the use of low quality SARS-CoV-2 diagnosis kits in Ecuador and other developing countries.

\section{Supplementary information}

Supplementary information accompanies this paper at https://doi. org/10.1186/s12985-020-01445-4.

Additional file 1. Manufacturer's manual version provided with the "AccuPower SARS-CoV-2 Real Time RT-PCR" kit used on this study.

\section{Abbreviations \\ CDC: Center for Disease Control and Prevention, USA; EUA: Emergency Use Authorization; FDA: Food and Drug Administration.}

\section{Acknowledgements}

We thank the authorities from Universidad de Las Américas, for logistic support to make SARS-CoV-2 diagnosis possible in our laboratory.

\section{Authors' contributions}

Byron Freire-Paspuel and Miguel Angel García Bereguiain analyzed the data and wrote the manuscript. All authors read and approved the final manuscript.

Funding

This study was funded by Universidad de Las Américas (Quito, Ecuador).

Availability of data and material

All relevant data is included in the manuscript.

Ethics approval and consent to participate

All samples have been submitted for routine patient care and diagnostics. Ethics approval was not sought because the study involves laboratory validation of test methods and the secondary use of anonymous pathological specimens that falls under the category'exempted'by "Comité de Etica para Investigación en Seres Humanos" from "Universidad de Las Américas".

\section{Consent to publication}

NA.

\section{Competing interests}

All authors have no conflict of interest to declare.

Received: 14 September 2020 Accepted: 5 November 2020 Published online: 14 November 2020

\section{References}

1. https://www.fda.gov/medical-devices/emergency-situations-medic al-devices/emergency-use-authorizations. Last accession date 09 April 2020.

2. Xiaoyan Lu, Wang L, Sakthivel SK, Whitaker B, Murray J, Kamili S, Lynch B, Malapati L, Burke SA, Harcourt J, Tamin A, Thornburg NJ, Villanueva JM, Lindstrom S. US CDC real-time reverse transcription PCR panel for detection of severe acute respiratory syndrome coronavirus 2. Emerg Infect Dis. 2020;26:8.

3. Interim Guidelines for Collecting, Handling, and Testing Clinical Specimens from Persons for Coronavirus Disease 2019 (COVID-19). Center for 
Diseases Control and Prevention, USA. https://www.cdc.gov/coronaviru s/2019-ncov/lab/guidelines-clinical-specimens.html. Last access 04 Sept 20.

4. Rhoads DD, Cherian SS, Roman K, Stempak, LM, Schmotzer CL, Sadri N. Comparison of Abbott ID Now, Diasorin Simplexa, and CDC FDA EUA methods for the detection of SARS-CoV-2 from nasopharyngeal and nasal swabs from individuals diagnosed with COVID-19. Accepted Manuscript Posted Online 17 April 2020. J Clin Microbiol. doi:https://doi. org/10.1128/JCM.00760-20.

5. Nalla AK, Casto AM, Huang M-LW, Perchetti GA, Sampoleo R, Shrestha L, Wei Y, Zhu H, Jerome KR, Greninger AL. Comparative performance of SARS-CoV-2 detection assays using seven different primer/probe sets and one assay kit. JCM Accepted Manuscript Posted Online 8 April 2020. J Clin Microbiol. doi:https://doi.org/10.1128/JCM.00557-20.

6. Freire-Paspuel B, Vega-Mariño P, Velez A, Castillo P, Cruz M, Garcia-Bereguiain MA. Evaluation of nCoV-QS (MiCo BioMed) for RT-qPCR detection of SARS-CoV-2 from nasopharyngeal samples using CDC FDA EUA qPCR kit as a gold standard: an example of the need of validation studies. J Clin Virol. 2020 May 22; 128:104454. doi:https://doi.org/10.1016/j. jcv.2020.104454.

7. Ki HH et al. On behalf of Korean Society for Laboratory Medicine, COVID-19 Task Force and the Center for Laboratory Control of Infectious Diseases, the Korea Centers for Disease Control and Prevention. Guidelines for Laboratory Diagnosis of Coronavirus Disease 2019 (COVID19) in Korea. Ann Lab Med. 2020;40:351-360. https://doi.org/10.3343/ alm.2020.40.5.351.

8. Freire-Paspuel B, Vega-Mariño P, Velez A, Castillo P, Gomez-Santos EE, Cruz M, Garcia-Bereguiain MA. Cotton-tipped plastic swabs for SARS-CoV-2
RT-qPCR diagnosis to prevent supply shortages. Front Cell Infect Microbiol. 2020;10:356. doi: https://doi.org/10.3389/fcimb.2020.00356. eCollection 2020.

9. Freire-Paspuel B, Vega-Mariño P, Velez A, Castillo P, Cruz M, GarciaBereguiain MA. Sample pooling of RNA extracts to speed up SARS-CoV-2 diagnosis using CDC FDA EUA RT-qPCR kit. Virus Res. 2020, 290, 198173.

10. Freire-Paspuel B, Garcia-Bereguiain MA. Analytical sensitivity and clinical performance of a triplex RT-qPCR assay using CDC N1, N2 and RP targets for SARS-CoV-2 diagnosis. Int J Infect Dis. 2020. In press. https://doi. org/10.1016/j.jijid.2020.10.047.

11. Freire-Paspuel B, Vega-Mariño P, Velez A, Castillo P, Masaquiza C, CedeñoVega R, Lozada T, Cruz M, Garcia-Bereguiain MA. One health" inspired SARS-CoV-2 surveillance: the Galapagos Islands experience. One Health. 2020. In press. https://doi.org/10.1016/j.onehlt.2020.100185

12. Lavezzo E et al. Suppression of a SARS-CoV-2 outbreak in the Italian municipality of Vo'. Nature. Accelerated Article Preview Published online 30 June 2020. https://doi.org/10.1038/s41586-020-2488-1 (2020).

13. Kleiboeker S, Cowden S, Grantham J, Nutt J, Tyler A, Berg A, Altrich M. SARS-CoV-2 viral load assessment in respiratory samples. J Clin Virol. 2020. https://doi.org/10.1016/j.jcv.2020.104439.

\section{Publisher's Note}

Springer Nature remains neutral with regard to jurisdictional claims in published maps and institutional affiliations.
Ready to submit your research? Choose BMC and benefit from:

- fast, convenient online submission

- thorough peer review by experienced researchers in your field

- rapid publication on acceptance

- support for research data, including large and complex data types

- gold Open Access which fosters wider collaboration and increased citations

- maximum visibility for your research: over $100 \mathrm{M}$ website views per year

At BMC, research is always in progress.

Learn more biomedcentral.com/submissions 